\title{
NON-FORMAL ISLAMIC EDUCATION FOR WOMEN PRISONER IN RUMAH TAHANAN NEGARA
}

\author{
Hasan Asari ${ }^{1}$, Saiful Akhyar Lubis ${ }^{2}$, Hayatun Sabariah ${ }^{3}$ \\ Universitas Islam Negeri Sumatera Utara Medan, Indonesia ${ }^{1,2,3}$ \\ E-mail: hayatunsabariah395@gmail.com
}

\begin{abstract}
The increasing number of crimes that have occurred has caused Rumah Tahanan Negara to carry out coaching activities for prisoners, especially in non-formal education. Islamic religious education is not only carried out in school institutions in Rumah Tahanan Negara education for prisoners has also been implemented, which aims to change attitudes and behavior, especially for female prisoners. This research uses a descriptive qualitative method. The data collection technique was carried out by interview, observation, and documentation, while the data analysis method used data reduction, data presentation, and verification, and conclusion. The purpose of this study was to analyze the management, material, supporting, and inhibiting factors of nonformal Islamic education for female prisoners in Rumah Tahanan Negara Klas II B Tanjung Pura Langkat. The results showed that non-formal Islamic education consisted of fostering personality and independence, eradicating literacy in the Koran, group dynamics and leadership, introduction to Islamic religious knowledge, the Islamic creed, jurisprudence, morals, and the history of Islamic culture. The supporting factors are the cooperation of various parties, the attitude of the prisoners, facilities, and the majority of Muslim women. Inhibiting factors are the lack of budget for Rumah Tahanan Negara, teaching staff, and the schedule of Islamic education.
\end{abstract}

Keywords: non-Formal Islamic education, Female prisoners, Moral Education,

\section{Abstrak}

Meningkatnya kriminalitas yang terjadi, menyebabkan Rumah Tahanan Negara melakukan kegiatan pembinaan bagi narapidana khususnya dalam pendidikan non-formal. Pendidikan agama Islam tidak hanya dilaksanakan di lembaga sekolah saja, di Rumah Tabanan Negara juga telah diberlakukan pendidikan untuk narapidana yang bertujuan untuk merubah sikap dan perilaku terutama bagi narapidana perempuan. Penelitian ini menggunakan metode kualitatif deskriptif. Teknik pengumpulan data dilakukan dengan wawancara, observasi dan dokumentasi, sedangkan metode analisis data menggunakan reduksi data, penyajian data dan verifikasi dan konklusi. Tujuan penelitian ini adalah menganalisis pengelolaan, materi, faktor pendukung dan penghambat pendidikan Islam non-formal bagi narapidana perempuan di Rumah Tahanan Negara Klas II B Tanjung Pura Langkat. Hasil penelitian menunjukkan bahwa pendidikan Islam non-formal terdiri dari pembinaan kepribadian dan kemandirian, pemberantasan buta aksara Alquran, dinamika kelompok dan kepemimpinan, pengantar ilmu agama Islam, akidah Islam, fikih, akblak dan sejarah kebudayaan Islam. Faktor pendukungnya adalah adanya kerjasama dari berbagai pibak, sikeap narapidana, fasilitas dan mayoritas muslimah. Faktor-faktor penghambat yakni kurangnya anggaran Rumah Tahanan Negara, tenaga pengajar dan jadwal pendidikan Islam.

Kata Kunci : pendidikan Islam non formal, Narapidana Perempuan, Pendidikan Moral 


\section{INTRODUCTION}

Various crimes such as theft, fraud, persecution, gambling, narcotics abuse, and corruption can be heard on television and in newspapers. ${ }^{1}$ The increasing number of crimes that have occurred has caused State Detention Houses to carry out coaching activities for inmates to receive guidance, especially in non-formal education. It is hoped that criminals can change their negative behavior and attitudes when interacting with the wider community after completing their prison term.

Living a life as a prisoner is a form of life that requires suffering. A person who experiences a crisis of meaning in his life, the prisoner cannot accept the situation at hand, still experiences mental shock, feels helpless, guilty, blame life, has a negative view of the future, and is unable to explore meaning in his life. ${ }^{2}$

Initially, the crime perpetrated by women was limited to prostitution and abortion. However, over time and changing social conditions make women involved in various crimes such as moneylenders, fraud, armed robbery, drug couriers, murder and even becoming members of criminal organizations. In the view of the general public, criminal acts are usually committed by men, on the other hand, the image of women is avoided from criminal acts. However, this view is starting to fade with the number of criminal cases committed by women. This contrasts with its image as the last bastion of widespread criminal or a-moral behavior. ${ }^{3}$

Religion is a form of God's regulation that humans use as guidance in living life in this world and the hereafter. Meanwhile, Islam teaches how humans behave and behave, which is always in the corridor of norms to reach the pleasure of Allah SWT. ${ }^{4}$

Islamic religious education is not only carried out in school institutions in State Detention Houses, education for prisoners has also been implemented, aimed at restoring the prisoners' understanding of the crimes they have committed. Islamic religious education taught to prisoners is guided by the Koran and hadith, which carries material on the eradication of literacy in the Qur'an, group dynamics, introduction to Islam, Islamic faith, jurisprudence, morals, and the history of Islamic culture. ${ }^{5}$

In the aim of the correctional rules which restore prisoners to become good citizens, and also aim to protect the community against the possibility of repeating criminal acts by inmates, as well as an application and an integral part of the values contained in Pancasila. ${ }^{6}$

${ }^{1}$ Noor Malihah dan Agus Wijayanto, "Implementasi Kurikulum Pembinaan Pendidikan Agama Islam di Rumah Tahanan Negara Kelas IIB Salatiga," INFERENSI: Jurnal Penelitian Sosial Keagamaan 12, no. 2 (31 Januari 2019): p 350, https://doi.org/10.18326/infs13.v12i2.349-370.

2 Siti Thohurotul Ula, "Makna Hidup Bagi Narapidana," Hisbab: Jurnal Bimbingan Konseling dan Dakwah Islam 11, no. 1 (1 Juni 2014): p 15, https://doi.org/10.14421/hisbah.2014.111-02.

3 Wanda Fitri, "Perempuan dan Perilaku Kriminalitas: Studi Kritis Peran Stigma Sosial Pada Kasus Residivis Perempuan," Kafa `ab: Journal of Gender Studies 7, no. 1 (22 Juni 2017): p 68, https://doi.org/10.15548/jk.v7i1.155.

4 Totong Heri, "Pembinaan Kesadaran Beragama Sebagai Upaya Peningkatan Pemahaman Agama Islam Di Lapas Kelas IIB Anak Wanita Tangerang," Jurnal Pendidikan Islam 10, no. 2 (30 November 2019): p 143, https://doi.org/10.22236/jpi.v10i2.3966.

${ }^{5}$ Romi, Head Rumah Tahanan Negara Klas II B Tanjung Pura Langkat, interview, 14 November 2019.

${ }^{6}$ Adi Sujatno, Sistem Pemasyarakatan Indonesia: Membangun Manusia Mandiri (Jakarta: Depkeh \& HAM, 2004), p 21. 
Assumptions that have never been imagined in the mind, regarding how the life of a State Prison with the hustle and bustle of life in a State Prison. What often happens is the ignorance that there is education that is carried out in a State Detention Center and how that education is given. Because the people assume that if you live in a State Detention Center your life feels good because you only eat and sleep. Another assumption develops that people who are in State Detention Centers are people who are far from Allah SWT. which results in doing bad things such as corruption, robbery, defamation, fraud, and so on.

When researchers saw firsthand the condition of female prisoners in State Detention Centers and interacted with several prisoners living in State Detention Centers. It can be observed that crime does not only occur due to economic conditions, but a higher influence occurs in crime due to cultural aspects. Poor religious knowledge and understanding contributed to the increase in the crime rate. ${ }^{7}$

With this, it has led Rumah Tahanan Negara to apply religious education to normalize life in Rumah Tahanan Negara. The religious education program inevitably has to be implemented in Rumah Tahanan Negara. It's hoped that with this religious education, the inmates can change their quality for the better.

Embedding religious values in Rumah Tahanan Negara is the initial foundation for reforming the morals of prisoners in Rumah Tahanan Negara. By applying religious values and conveying support to live a good life so that good morals will be creat. Humans are creatures of Allah SWT. Who has reason and mind and continues to move dynamically towards a happy life in the hereafter.

The formation of religion for prisoners is a foundation that provides a mentality in society so that prisoners can adapt after leaving Rumah Tahanan Negara with better morals than before, and are support by the knowledge and skills they have acquired in Rumah Tahanan Negara. The teachings of Islam, moral development is an important issue for every individual or group. ${ }^{8}$

Islamic education efforts are carried out in Rumah Tahanan Negara for prisoners to make a better person and can accept among the community after completing a period of detention. And not only that, Islamic education provided can also be useful for prisoners for spiritual formation. Islamic education will become self-control for prisoners because it is expected to be able to carry out religious activities properly, and ethically in society.

Based on the above explanation, the researcher views that Islamic religious education is very important to be implemented in State Detention Centers as a basis for spiritual strengthening in non-formal education. This is especially so for individuals who are outside the lines of life's rules. Punishment is present as statutory law as the application of law for people who violate it. Even though prisoners are people who violate the law, prisoners must also get their rights as stipulated in Law Number 12 of 1995 concerning Corrections, article

7 Apriyanti, Prisoner at Rumah Tahanan Negara Klas II B Tanjung Pura Langkat, interview, 21 November 2019.

${ }^{8}$ Herman Pelani, Bahaking Rama, dan Wahyuddin Naro, "Kegiatan Keagamaan Sebagai Pilar Perbaikan Perilaku Narapidana Di Lembaga Pemasyarakatan Wanita Kelas IIA Sungguminasa Gowa,” Jurnal Diskursus Islam 6, no. 3 (24 Desember 2018): p 449, https:/ / doi.org/10.24252/jdi.v6i3.6545. 
14 points (a), (b), and (c), namely: prisoners have the right performing worship by religion or belief, obtain good physical and spiritual care, and obtain education and teaching.

With the existence of Islamic education, it's hoped that the prisoners will be able to convert and return to the right path and be strong in living their post-prison life. Become a better human being and useful to the public.

Talking about women, etymologically the notion of women comes from the word empire, which means "master", a person who is skilled and powerful, the head, the upstream, the greatest. ${ }^{9}$ In Zaitunah Subhan's book, a woman comes from the word empu which means to be respected. ${ }^{10}$ In Murthada Muthahari's book, scientists like Plato said that in terms of physical and spiritual strength, women are weaker mentally than men. Meanwhile, the description of women according to a view based on medical, psychological, and social studies is divided into two factors, namely physical and psychological factors. ${ }^{11}$

Biologically from a physical point of view, women have differences with men, their voices are smoother, women's body development is earlier, women's strength is not like men's strengths, and so on. Women have a calmer nature, feel that they cry more quickly, and even faint when facing more severe problems. ${ }^{12}$

Meanwhile, Kartini Kartono said that the physiological differences experienced by women from birth, in general, would then be strengthened by the existing cultural structures, especially by customs, socio-economic systems, educational influences. ${ }^{13}$ In the concept of gender, it is said that the differences in a trait inherent in both men and women are the result of social and cultural construction. For example, women are known to be gentle, affectionate, graceful, beautiful, polite, emotional, or motherly and need protection. ${ }^{14}$

The thing that attracted the attention of researchers raised women as research material because the encouragement of researchers' curiosity towards women who were seen in a physical and psychological state could commit criminal acts. This is because, in general, men who commit crimes frequently and are dominant. Researchers are also motivated to find out about the implementation of non-formal Islamic education provided by Rumah Tahanan Negara for women.

\section{METHOD}

Based on the approach, this research is qualitative research oriented towards a descriptive qualitative approach. (Suharsimi Arikunto, 2002: 11) This descriptive qualitative approach aims to describe certain situations that are pursued through systematic, factual, and accurate sensing of the facts and population characteristics of a particular area. ${ }^{15}$

\footnotetext{
${ }_{9}^{9}$ Abdulsyani, Sosiologi: Skematika, Teori Dan Terapan (Jakarta: Bumi Aksara, 1994), p 45.

${ }^{10}$ Zaitunah Subhan, Kodrat Perempuan: Takdir Atau Mitos? (Yogyakarta: Pustaka Pesantren, 2004), p 1.

${ }_{11}$ Murtadha Muthahhari, Hak-Hak Wanita Dalam Islam (Jakarta: Lentera, 1997), p 107.

12 Muthahhari, p 108.

13 Kartini Kartono, Psikologi Wanita 1: Mengenal Gadis Remaja \& Wanita Dewasa (Bandung: CV. Mandar Maju, 2019), p 4.

${ }^{14}$ Mansour Fakih, Analisis Gender dan Transformasi Sosial (Yogyakarta: Pustaka Pelajar, 2005), p 9.

15 Muhammad Fauzy Emqi, "Model Pembelajaran Pendidikan Agama Islam Dalam Pembinaan Mental Narapidana (Studi Multikasus di Lembaga Pemasyarakatan Kelas I Malang Dan Lembaga Pemasyarakatan Wanita Kelas II-A Malang)," J-PAI: Jurnal Pendidikan Agama Islam 1, no. 1 (30 Desember 2014): p 59, https://doi.org/10.18860/jpai.v1i1.3359.
} 
This research was conducted using a qualitative approach, which is an approach that is directed at the background and the individual as a whole and also as a research procedure that produces descriptive data, namely a study in the form of written words and not numbers (Faisal Sanapiah, 1982). A qualitative approach is used to examine natural objects, directly to the data source, and the research instrument is the researcher himself. ${ }^{16}$

In this study, researchers used exploratory descriptive. In the implementation of the research, the researcher observed the activities carried out by inmates in the prison when participating in religious formation activities. Through these activities, researchers can explain the state or status of phenomena to describe things related to the state of something, namely describing things related to the state of something, namely the Islamic religious education model in mental development. ${ }^{17}$

In this study or research uses descriptive research with qualitative methods, in which descriptive research is not intended to test certain hypotheses, not to describe "what is" about a variable, symptom, or condition. ${ }^{18}$ Qualitative research is often called "naturalistic research" because the research is carried out in natural conditions (natural setting). ${ }^{19}$

Moleong argues that qualitative research is research that intends to understand the phenomena experienced by research subjects; for example motivation, perception, behavior, action, and so on holistically and by describing it in words and language in a special natural context by utilizing various natural methods. ${ }^{20}$ In this case, the researcher seeks to describe the non-formal Islamic education for female prisoners at Rumah Tahanan Negara Klas II B Tanjung Pura Langkat.

The research period was started from September 2019 to May 2020. The research site was carried out at Rumah Tahanan Negara Klas II B Tanjung Pura Langkat, Jl Binjai Tanjung Pura, No. 12 Langkat, Pekan Tanjung.Pura, Stabat Kabupaten Langkat, Sumatera Utara.

In data collection, the researcher acts as a research instrument to see one case with various sub-cases. According to Guba and Lincoln in Moleong, the general characteristics of humans as instruments include responsiveness, adaptability, emphasize wholeness, base oneself on knowledge, process data as quickly as possible, take advantage of opportunities to classify and exploit and use unusual or idiosyncratic responses. ${ }^{21}$

The research data collection was obtained from various sources, as follows: The Head Rumah Tahanan Negara, who acts as the person in charge of the institutions in Rumah Tahanan Negara Tanjung Pura, both about planning, implementing programs, and managing them, employees/staff, play a role as assistants in managing and executing Rumah Tahanan Negara so that the objectives that have been designed can run well and smoothly, extension

16 Hasbiyallah Hasbiyallah dan Siti Fadhilah Asy-Syari, "Pelaksanaan Pendidikan Agama Islam Bagi Narapidana Kasus Korupsi," Atthulab: Islamic Religion Teaching and Learning Journal 4, no. 1 (18 Februari 2019): p 112, https://doi.org/10.15575/ath.v4i1.2862.

17 Emqi, "Model Pembelajaran Pendidikan Agama Islam Dalam Pembinaan Mental Narapidana (Studi Multikasus di Lembaga Pemasyarakatan Kelas I Malang Dan Lembaga Pemasyarakatan Wanita Kelas II-A Malang)," p 59.

18 Suharsimi Arikunto, Manajemen Penelitian (Jakarta: Rineka Cipta, 2009), p 310.

19 Andi Prastowo, Metode Penelitian Kualitatif: Dalam Perspektif Rancangan Penilitian (Yogyakarta: Ar-Ruzz Media, 2013), p 22.

${ }^{20}$ Lexy J Meleong, Metologi Penelitian Kualitatif(Bandung: PT Remaja Rosdakarya, 1989), p 6.

${ }^{21}$ Meleong, p 121. 
workers (teachers / Ustaz), as providers of Islamic studies in religious activities in this Rumah Tahanan Negara, and prisoners, whose position is the object and subject of educational research and guidance at Rumah Tahanan Negara Klas II B Tanjung Pura Langkat. Data analysis techniques, namely researchers reduce data, present data, and draw conclusions or verification. Data obtained from interviews, observation, and documentation.

\section{RESULTS AND DISCUSSION}

The term convict is regulated in Law Number 12 of 1995 in Article 1 paragraphs 5 and 7 , which states that prisoners are included in prisoners. In this article, it is explained that "Correctional assistants are prisoners of correctional students and correctional clients. (Law number 12 of 1995 regarding conventionalization of article 1 paragraph 5). ${ }^{22}$

Rumah Tahanan Negara Klas II B Tanjung Pura Langkat is one of the Technical Implementing Units at the Regional Office of Kementerian Hukum and HAM Sumatera Utara which has the main duties and functions of the correctional for prisoners and students as well as detention services as technical implementers of Law Number 12 of 1995 concerning Corrections.

Rumah Tahanan Negara Klas II B Tanjung Pura Langkat was originally a Dutch colonial heritage building which is not known for the year it was founded. In 1964 with the birth of the Correctional System, it was changed to the name Rumah Tahanan Negara Tanjung Pura Branch. Changed its name in 1996 to the name Rumah Tahanan Negara Klas II B Tanjung Pura to the present. ${ }^{23}$

Figure 1. Structure of Rumah Tahanan Negara Klas II B Tanjung Pura

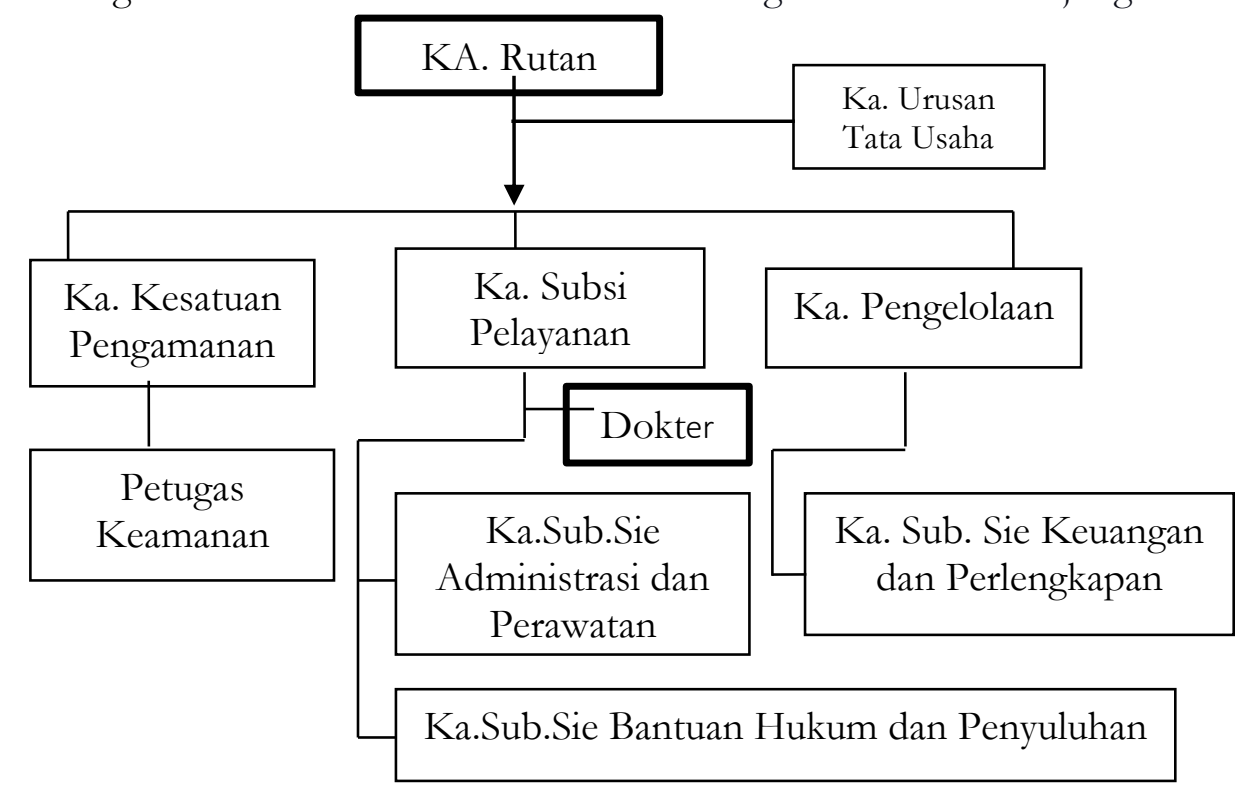

Source: Data Collection Rumah Tahanan Negera

22 Emqi, "Model Pembelajaran Pendidikan Agama Islam Dalam Pembinaan Mental Narapidana (Studi Multikasus di Lembaga Pemasyarakatan Kelas I Malang Dan Lembaga Pemasyarakatan Wanita Kelas II-A Malang)," p 58.

${ }^{23}$ Meleong, Metologi Penelitian Kualitatif. 
Based on data obtained from the personnel department, currently, there are 63 employees and only 38 people are security officers (as of 25 July 2019), most of whom are high school graduates.

It has been previously explained that the assessment carried out at Rumah Tahanan Negara Klas II B Tanjung Pura Langkat limits the status of female prisoners who are Muslim only. Prisoners are obliged to participate in activities at Rumah Tahanan Negara Klas II B Tanjung Pura Langkat, which is essential for every Muslim prisoner.

The occupants Rumah Tahanan Negara Klas II B Tanjung Pura are also called prisoners. Correctional officers are obliged to provide legal guarantees for fair treatment without discrimination. ${ }^{24}$ Prisoners in carrying out guidance must obtain facilities and fulfillment of rights and are obliged to carry out obligations according to applicable regulations.

The building capacity of Rumah Tahanan Negara Klas II B Tanjung Pura is 145 people but currently, it is filled with 727 people (as of July 25, 2019) who are accommodated in 27 rooms in five blocks for male residents and one block for female residents. Based on the data obtained by the author, the number of prisoners in Rumah Tahanan Negara Klas II B Tanjung Pura can be seen in the following:

Table 2. Classification of Prisoners in Rumah Tahanan Negara Klas II B Tanjung Pura

\begin{tabular}{ccccccccc}
\hline $\begin{array}{c}\text { Classific } \\
\text { ation }\end{array}$ & \multicolumn{2}{c}{$\begin{array}{c}\text { Convicts } \\
\text { Adult }\end{array}$} & \multicolumn{2}{c}{ Convict Child } & Prisoner Adult & \multicolumn{2}{c}{$\begin{array}{c}\text { Prisoner } \\
\text { Child }\end{array}$} \\
\hline & Men & Woman & Men & Woman & Men & Woman & Men & Adult \\
Total & 409 & 20 & 4 & - & 295 & 6 & 2 & 0 \\
& 420 & & 4 & & 301 & 2 & 2
\end{tabular}

* Data Sources: Data on Classification of Prisoners at Rumah Tahanan Negara Klas II B Tanjung Pura 25, 2019

Table 3. Number of Inmates Rumah Tahanan Negara Klas II B Tanjung Pura

\begin{tabular}{ccccc}
\hline $\mathbf{N}$ & Capacity & Total Inmates & Excess Capacity & Year \\
$\mathbf{0}$ & & & & \\
\hline $\mathbf{1}$ & 145 & 582 & $301 \%$ & 2017 \\
$\mathbf{2}$ & 145 & 663 & $357 \%$ & 2018 \\
$\mathbf{3}$ & 145 & 727 (as of July 25) & $393 \%$ & 2019 \\
\hline
\end{tabular}

* Data source: Data of Inmates of Rumah Tahanan Negara Klas II B Tanjung Pura.

Table 4. Crime Violations of Prisoners in Rumah Tahanan Negara Klas II B Tanjung Pura Langkat

\begin{tabular}{ccc}
\hline $\mathbf{N}$ & Criminal Group & Total \\
$\mathbf{o}$ & & \\
\hline $\mathbf{1}$ & General Crime & 278 people \\
\hline
\end{tabular}

${ }^{24}$ C. S. T. Kansil dan Christine S. T. Kansil, Hukum Tata Negara Republik Indonesia, Ed. rev (Jakarta: Rineka Cipta, 2000), p 85. 


\begin{tabular}{llc}
\hline $\mathbf{2}$ & Drugs & 444 people \\
$\mathbf{3}$ & Corruption & 5 people
\end{tabular}

Total

727 people

* Data Source: Data on Crime Violations of Prisoners in Rumah Tahanan Negara Klas II B Tanjung Pura

Currently, functional religious extension agents are faced with a rapidly changing social condition that leads to a functional society, a technological society, a scientific society, and an open society. Thus, every functional religious extension worker needs to continuously improve his knowledge, insight, and self-development, and also need to understand the vision of the religious extension agent and optimally master the material of religious extension itself and its delivery techniques. ${ }^{25}$

Extension or ustaz or ustazah of non-formal Islamic education for prisoners at Rumah Tahanan Negara Klas II B Tanjung Pura Langkat originated in the collaboration of Kementerian Agama Kabupaten Langkat with 9 extension personnel, with details of 4 male and 5 female extension officers.

Table 5. Religious Counseling Data

\begin{tabular}{cll}
\hline No & \multicolumn{1}{c}{ Name } & \multicolumn{1}{c}{ Activities } \\
\hline $\mathbf{1}$ & Salmilawati Hasanah, S.Pd.I & Islamic Religious Counseling \\
$\mathbf{2}$ & Fitri Khairiah, S.Pd.I & Islamic Religion Counseling \\
$\mathbf{3}$ & Syair Nursiah, S.Pd.I & Islamic Religion Counseling \\
$\mathbf{4}$ & Ali Imran, S.Ag & Islamic Religion Counseling \\
$\mathbf{5}$ & Muhammad Duha, S.Pd.I & Islamic Religion Counseling \\
$\mathbf{6}$ & Adam Asli Syariat, S.H.I & Islamic Religion Counseling \\
$\mathbf{7}$ & Agus Saat, S.Pd.I & Islamic Religion Counseling \\
$\mathbf{8}$ & Herawati, S. Sy & Islamic Religion Counseling \\
$\mathbf{9}$ & Sri Wahyuni, S.Pd.I & Islamic Religion Counseling \\
\hline Data Source: Islamic Religious Counseling Kementerian Agama Kabupaten Langkat
\end{tabular}

In general, the management of non-formal Islamic education for female prisoners at Rumah Tahanan Negara Klas II B Tanjung Pura Langkat has collaborated with religious counselors from Kementerian Agama Kabupaten Langkat. As stated in Law Number 12 of 1995 concerning Corrections. Regarding correctional directives, it is a part that leads to the limit of the method of guiding prisoners based on the perspective of life to implement a commitment between the supervisor and the fostered as well as the social environment for the quality of prisoners to become better, pious, faithful and responsible people to themselves, their families and the environment. socialize so that one day they can optimize themselves into the community as a social being who is free to socialize.

${ }^{25}$ Muchlis, "Peran Penyuluh Agama Islam Fungsional dalam Melakukan Pembinaan terhadap Narapidana di Rumah Tahanan Kelas II-B Kabupaten Bangkalan (Perspektif Komunikasi Sosial dan Agama)," Dirasah : Jurnal Studi Ilmu dan Manajemen Pendidikan Islam 3, no. 2 (8 Agustus 2020): p 15, https://doi.org/10.29062/dirasah.v3i2.123. 
Implementing the management of Islamic education at Rumah Tahanan Negara Klas II B Tanjung Pura by applying management functions, namely: Planning, Organizing, Implementing, and Supervision.

Non-formal Islamic planning in Rumah Tahanan Negara Klas II B Tanjung Pura. In the implementation of Islamic education in Rumah Tahanan Negara must have a plan. Several aspects of planning are related to the implementation of learning.

From the researcher interview with Kepala Rumah Tahanan Negara Tanjung Pura, Mr. Parlindungan Siregar, that:

The management of Islamic education at Rumah Tahanan Negara Tanjung Pura is based on law No. 12 of 1995 concerning Corrections, but with a variety of problems that are committed by prisoners, because of that the most important effort to implement Islamic education for prisoners is to make a program plan with existing provisions in Rumah Tahanan Negara with part of the existing subsection order. And collaborate with third parties. All this is done so that the process of Islamic education for prisoners runs smoothly and successfully. ${ }^{26}$

The same thing was conveyed by Mr. Iriadi, Kasubsi Pelayanan Tahanan Rumah Tahanan Negara Klas II B Tanjung Pura Langkat in the management of Islamic education as follows:

In the management of Islamic education at Rumah Tahanan Negara Tanjung Pura, we plan, for example, we design an Islamic education program for female prisoners by scheduling religious activities, prayer schedules for five times, Friday sermons, and tausiyah with the material we have determined. In this plan, it collaborates with Kementerian Agama to deliver religious tausiyah which is carried out once every 2 weeks every Thursday. Islamic education is very much needed by prisoners, therefore we, Rumah Tahanan Negara collaborate with the Kementerian Agama in fostering prisoners whose management and implementation still have many shortcomings due to limited personnel and adequate facilities, even though we, Rumah Tahanan Negara have done Maximum efforts are made for the realization of Islamic religious education for prisoners and it is hoped that with this activity the prisoners are aware and do not commit criminal acts anymore. ${ }^{27}$

The guidance aims so that when the prisoner has completed his prison term, it is expected that he will not repeat his actions (crimes) and can live in a normal society and be able to participate in development (Halimah Puti, 2014) ${ }^{28}$ Guidance for prisoners is any effort or activity carried out by officers of the Class II B Yogyakarta Women's Prison through a correctional program that aims to grow, develop and increase the potential that exists in the

${ }^{26}$ Parlindungan Siregar, Head of Rumah Tahanan Negara Klas II B Tanjung Pura Langkat, interview, 13 Januari 2020.

${ }^{27}$ Iriadi, Kasubsi Pelayanan Tahanan Rumah Tahanan Negara Klas II B Tanjung Pura Langkat, interview, 15 Januari 2020, Rumah Tahanan Negara.

${ }^{28}$ Rina Saraswaty, Suprayitno, dan Salamiah Sari Dewi, "Pemberdayaan Napi Perempuan Di LP Tanjung Gusta Kecamatan Medan Helvetia, Medan, Sumatera Utara," Randang Tana - Jurnal Pengabdian Masyarakat 3, no. 3 (2020): p 143, https://doi.org/10.36928/jrt.v3i3.644. 
Correctional Assistance Society. Guidance to increase the spirituality of prisoners is very important so that each individual can internalize the divine values that exist in the heart to reach a holy heart point (God spot). ${ }^{29}$

The management of the penitentiary system for the assisted citizens strives for a program of guidance, education, care and guidance for prisoners who intend to improve the social and human rights of individuals with a social and state environment.

Law Number 12 of 1995 concerning Corrections: The religious education program is a structured and directed form. It is the right thing for prisoners in the criminal law period by filling in religious activities to change their behavior, improve the religious lifestyle manifested in the activities of prisoners in Rumah Tahanan Negara.

Prisoners have a low level of Islamic religious education, including formal education, informal education, and non-formal education with different family backgrounds and environments, making it one of the factors for them to violate the law.

Prisoners have different levels of faith and faith, which requires intensive and directed direction. This Islamic education has multifunctionality, firstly as an obligation as a Muslim and secondly as a form of treatment or personality therapist to change one's habits for the better in religion and society. ${ }^{30}$

The implementation of this education or religious guidance uses a variety of methods, both the tausyiah sermon or lecture methods, so that the educational goals of this coaching are planned and directed, there is a need for other programs so that they can achieve useful goals and objectives for prisoners.

A program that is planned and directed systematically requires an effective curriculum in its implementation, in its implementation through Direktorat Jenderal Pemasyarakatan has summarized the form of a model guide or curriculum for Islamic education in Lembaga Pemasyarakatan in the implementation of prison development which consists of Islamic education materials.

The material taught in the da'wah program, namely the eradication of illiteracy of the Qur'an, group dynamics and leadership, introduction to Islamic religious knowledge, morals, fiqh, the history of Islamic culture. In managing the da'wah program for female prisoners, Rumah Tahanan Negara collaborates with the Kementerian Agama. This da'wah program is held every two weeks on Thursdays from 10:00 a.m. to 12:00 p.m. With the development of schedules and scheduling of Islamic education based on the Koran and Hadith.

The organization of non-formal Islamic education for female prisoners at Rumah Tahanan Negara Klas II B Tanjung Pura Langkat was revealed through an interview with the Head Rumah Tahanan Negara Mr. Perlindungan Siregar, that:

This organization in Rumah Tahanan Negara is carried out by planning all work carried out to achieve organizational goals, carrying out organizational structures, providing workloads to activities that are reasonable and efficient, and estimating

29 Yulia Khoerunnisa dan Muhammad Rosyid Ridla, "Strategi Peningkatan Spiritualitas Narapidana Di Lembaga Pemasyarakatan: Studi Pada Lapas Perempuan Kelas II B Yogyakarta," Jurnal MD 6, no. 1 (2020): p 75, https://doi.org/10.14421/jmd.2020.61-04.

30 Direktorat Jenderal Pemasyarakatan Kementerian Kehakiman dan Hak Asasi Manusia RI, Petunjuk. Pelaksanaan Program Pendidikan Agama Islam Dengan Kurikulum Modul A bagi Narapidana Di Lembaga Pemasyarakatan dan Rumab Tabanan Negara (Jakarta, 2001), p 5-6. 
whether it can be carried out by employees or groups, combining group work using logical and efficient, establishing mechanisms to coordinate group work with the team to create cooperation as well as checking the effectiveness of organized group work and deciding appropriate steps to optimize or improve work. The administrative subsection, service sub-section, security sub-section, management sub-section, carry out their respective work sections. If for the convicts themselves we make a grouping by Law Number 12 of 1995 concerning Corrections, which in the classification of prisoners in Rumah Tahanan Negara we classify based on the basis, age, sex, length of sentence imposed, type of crime, and criteria. By the needs and institutional arrangements, each adult cell / room will be separated from prisoners who are minors. But in non-formal Islamic education they are united. And for its implementation, the process of activities can only be differentiated if it includes material about reading or learning the Koran, prisoners who are fluent in reading the Koran will be combined with inmates who can read the Koran, but who are not fluent in reading the Koran or are still learning Iqra ', then with prisoners who same. ${ }^{31}$

Based on the interview the researcher above concludes about structured organizing in carrying out activities by what has been planned. From the organizational structure of Rumah Tahanan Negara which is in line with Law Number 12 of 1995 concerning Corrections to the grouping of prisoners based on the period of sentence and age and the grouping in Islamic education in Rumah Tahanan Negara which is arranged based on the level of proficiency in understanding Islamic education material.

Implementation of non-formal Islamic education at Rumah Tahanan Negara Klas II B Tanjung Pura. Rumah Tahanan Negara are places where people who commit crimes that are heterogeneous in nature, both from the background of the case, education, religion, age, and social status in the community. Prisoners, who are often referred to as inmates, of course, need the values of Islamic education to reshape the prisoners' mental, moral, and spiritual life.

This stage is a series of activities by officers or individuals in carrying out spiritual activities to provide news about the norms established and compiled by Rumah Tahanan Negara. The implementation of non-formal Islamic education at Rumah Tahanan Negara Klas II B Tanjung Pura aims to improve bad prisoners into good ones so that prisoners can create good personalities in responding to the problems at hand.

In the series of implementation of Islamic education activities, it was explained by the Head Rumah Tahanan Negara Mr. Perlindungan Siregar, that:

The implementation of Islamic education in the State Detention Center is still based on Law Number 12 of 1995 concerning Corrections, with the aim that the prisoners here can realize the mistakes they have made, change their behavior, and are reluctant to commit crimes again, and later when the prisoners get out of prison can mingle with the community. ${ }^{32}$

The same thing was conveyed by Mr. Iriadi, Kasubsi Pelayanan Tahanan:

\footnotetext{
${ }^{31}$ Siregar, Head of Rumah Tahanan Negara Klas II B Tanjung Pura Langkat.

32 Siregar.
} 
In the implementation of Islamic education in this Rumah Tahanan Negara it is carried out every two weeks or half a month, starting from 10: 00-12: 00 noon, which is located on the 2nd floor of the building in Rumah Tahanan Negara, for special education activities for women, if for male prisoners we place them in the mosque Rumah Tahanan Negara because the number of male prisoners is more, and held every Friday as well as Friday prayers. ${ }^{33}$

Regarding the use of methods in the implementation of Islamic education in Rumah Tahanan Negara another expression from the coach or ustaz/ustazah:

In the implementation of non-formal Islamic education, which is implemented in Rumah Tahanan Negara, it is carried out every two weeks, starting at 10:00 am and ending at noon. In practice, we deliver material according to the existing curriculum. And it is not uncommon for us to develop existing materials, seeing from the prisoners' needs regarding Islam. And by using the lecture method, depending on the material presented. Meanwhile, we also use the group method when the material is about studying Iqra 'or the Koran. With the hope that they can understand the material well and can apply it in their future lives. ${ }^{34}$

The results of the interview above can the researchers conclude that the implementation of Islamic education at Rumah Tahanan Negara Klas II B Tanjung Pura Langkat is carried out within 2 weeks or half a month. Starting from 10.00-12.00 noon. With the existing material and in its delivery, the religious extension team developed the material according to the Qur'an and hadith. According to researchers, the implementation of Islamic education at Rumah Tahanan Negara Klas II B Tanjung Pura is an officer's concern for the prisoner's spirituality so that they are always decorated or nurtured and their tauhid by implementing Islamic education can be istiqomah (continuously) doing good things.

Supervision can be interpreted as a form of monitoring of activity to ensure that all activities can run as planned, as well as correcting and correcting if irregularities are found that will interfere with the achievement of goals.

The basis for supervision in Rumah Tahanan Negara is stated in the Decree of Keputusan Menteri Kehakiman Nomor. M.01.PR.07.03 the Year 1985 concerning the organization and work procedure of Rumah Tahanan Negara, which regulates two forms of supervision, namely inherent supervision and functional supervision. Inherent supervision is carried out by the head of the organizational unit while functional supervision is carried out by Inspektorat Jenderal Departemen Hukum and HAM.

Regarding the definition of supervision, whoever has the function of supervising and how the supervision is carried out is contained in the Presidential Instruction of the Republic of Indonesia No. 15 of 1983 concerning Guidelines for Supervision Implementation. The inherent supervision carried out by Rumah Tahanan Negara is stated in the Decree of Menteri Kehakiman Number. M.01.PR.07.03 the Year 1986 article 62 declares that each head of an organizational unit is obliged to supervise his / her respective subordinates and if there is any

33 Iriadi, Kasubsi Pelayanan Tahanan Rumah Tahanan Negara Klas II B Tanjung Pura Langkat.
${ }^{34}$ Syair Nursiah, Tanjung Pura Islamic Religion Conselor Team, interview, 16 Januari 2020. 
deviation to take the necessary steps by the applicable regulations. Then article 65 for every report received by the leadership from subordinates must be processed and used as material for further report preparation and to provide instructions to subordinates. Furthermore, the head of Rumah Tahanan Negara submits the report to the Head of the Regional Departmental Office Article 66.

Through an interview with the Head of Rumah Tahanan Negara Mr. Parlindungan Siregar, the supervision of non-formal Islamic education in Rumah Tahanan Negara is carried out as follows:

As the Head of Rumah Tahanan Negara here, I am responsible for any programmed activity, including non-formal Islamic education activities, usually the supervision that I carry out by examining activities, such as signing the absences of prisoners who participate in recitation in this Rumah Tahanan Negara and every activity must not deviate from the stipulated law. We will direct or instruct our employees to supervise activities by monitoring the progress of activities. And the way of monitoring at the entrance to Rumah Tahanan Negara has given identification, and after the recitation or guidance process we see whether the material presented is by the curriculum, and by the guidelines of the Qur'an and hadith. And from the results of the supervision of our employees, we will provide a letter of activity which is given the seal of Rumah Tahanan Negara, and usually we also provide a copy with counselors team of Kementerian Agama Kabupaten Langkat, as well as religious counselors, they also provide a copy of the topic of material submitted to prisoners to Rumah Tahanan Negara. The state is part of the cooperation to monitor and control each development activity in Rumah Tahanan Negara. ${ }^{35}$

The same thing was conveyed by Mr. Iriadi, Kasubsi Pelayanan Tahanan, that:

In the supervision of Islamic education activities, we do this by providing attendance for prisoners who take part in Islamic education recitation, and for the Ustaz/ustazah, every time they enter from our front door or guard the entrance to the prisoners will provide identification cards that are numbered and used and we record how many Ustaz/ustazah who come to give recitation, from this attendance we supervise every recitation activity that takes place. ${ }^{36}$

The results of the researcher interview with prisoner Mrs. Umi Kalsum who stated that:

In the material for reading and writing the Koran, we usually start by reading a few short chapters in the Koran, such as the easiest examples of surahs, Surah An-Nas, AlFalaq, Al-Ikhlas, when they understand and can read them fluently. will add another letter, for example reading surah Al-Ma'un, after that, it will be continued by reading

\footnotetext{
35 Siregar, Head of Rumah Tahanan Negara Klas II B Tanjung Pura Langkat.

${ }^{36}$ Iriadi, Kasubsi Pelayanan Tahanan Rumah Tahanan Negara Klas II B Tanjung Pura Langkat.
} 
the Koran, but for those of us who are not fluent in reading the Koran, we just use iqra' first, later we will be grouped with those who read Iqra' as well. ${ }^{37}$

This was confirmed by the ustazah Mrs. Syair Nursiah stated that:

For the reading and writing material of the Koran itself, we usually divide one hour for reading and the Koran and Iqra ', and the next hour we fill it with tausiyah relating to this week's theme or material, for example, halal and haram food, or about the verses of repentance. ${ }^{38}$

Group dynamics is a group consisting of two or more individuals who have a clear psychological relationship between members and one another and take place in a natural situation. $^{39}$

In conveying the composition of material on the dynamics of this group, we are more directed towards advising prisoners in this Rumah Tahanan Negara, that each of us is a social creature wherever we are, whether inside or outside of prison we are social beings which means that we need people inside. our life. There is neither the strongest nor the weakest in Rumah Tahanan Negara, all of them must look after and help each other, if there is a problem, they do not have to pull their hair. All can be resolved with a good chat. This is what we convey to them, respecting each other's opinions or other people's advice even though that advice also comes from prisoners in Rumah Tahanan Negara here. ${ }^{40}$

In an interview with prisoner, Mrs. Raodah, she said that:

Tausiyah given by ustazah about the dynamics of this group, we were taught to help each other. Even though in one cell we were like brothers, in the other cell we still needed to adjust, because many heads were not the same willing. Just respect each other when there are disagreements and sometimes we also ask the ustaz for solutions to our problems, sometimes we are reconciled with the ustazah. The word ustazah does not need to be quarrelsome and angry so that he does not greet, in this Rumah Tahanan Negara our family knows best that we are not people outside Rumah Tahanan Negara, so we must help each other keep selfish things that can self-destruct, that was conveyed. ustazah to us.

Prisoner Mrs. Umi Kalsum stated that:

Cooperation and mutual respect for fellow residents of Rumah Tahanan Negara here are needed, especially since we are from various ethnicities and our respective habits. Sometimes trivial things get big and messy when you have this it shows its true nature, which is tough, selfish, wants to win alone. In my opinion, trivial matters should not

${ }^{37}$ Umi Kalsum, Prisoner Rumah Tahanan Negara Klas II B Tanjung Pura Langkat, interview, 14 Januari 2020.

${ }^{38}$ Nursiah, Tanjung Pura Islamic Religion Conselor Team.

${ }^{39}$ Slamet Santosa, Dinamika Kelompok (Jakarta: Bumi Aksara, 1992), p 5.

${ }^{40}$ Nursiah, Tanjung Pura Islamic Religion Conselor Team. 
be widened anywhere, it can still be resolved with a good chat. Because of the clothesline alone, sometimes you don't give a warning until we ask for help to finish with the ustazah. Ustazah that always reminds us that we are social beings, we can't live as much as we want, because we need the help of others, especially in Rumah Tahanan Negara, where we are far from family, so our neighbors to help each other and respect one another. said ustazah. ${ }^{41}$

It can be concluded by the researcher that the cultivation of cooperation and mutual assistance, mutual respect between prisoner is conveyed in the material of group dynamics to create normality among fellow residents of Rumah Tahanan Negara, because each of us is a social creature who always needs other people in our lives.

The importance of religion for human life was also felt by the prisoner Mrs. Sri Astuti, she stated that:

For us who are in this prison, religion is very important, where when everyone ridicules us, we are shunned by our families, children, even when we are vulnerable and sad, tausiyah from ustazah about religion for life we feel we have hope to surrender to Allah for the evil deeds we have done in the past. Allah would want to open the door of forgiveness for us again, our belief in Allah makes us continue to affirm our hope and ask us to be strong and patient in serving our sentence here. ${ }^{42}$

The results of the researcher interview with the prisoner Mrs. Hidayatul Husna stated that:

We always ask about tawhid material when our faith comes down with our condition in Rumah Tahanan Negara, which is nervous, fragile, we don't know where to hope and complain, so the material of tawhid explained by ustazah makes us human beings who have guidelines not to give up because of our actions. that we have done before, we believe that Allah's grace. broad and also broad forgiveness, that is what the ustazah always implanted in us. ${ }^{43}$

Providing tausiyah fiqh or shari'ah regarding the practices of muamalah and pillars of Islam with the aim that later the prisoners can know the law in Islam, the law of worship, the law of muamalah, how to do dhikr and pray, various kinds of halal and haram foods that get a good response from the inmates to add to the excitement in delivering the material.

As the results of the analysis and interviews with Mrs. Salmilawati as the Head of the Tanjung Pura Islamic Religion counselor Team, she stated:

Usually, if the material about Shari'ah or fiqh is very complex, the material given is sometimes not enough time to explain the questions posed by prisoners, ranging from individual and group problems in the rooms of Rumah Tahanan Negara to other fiqh

\footnotetext{
${ }^{41}$ Kalsum, Prisoner Rumah Tahanan Negara Klas II B Tanjung Pura Langkat.

${ }^{42}$ Sri Astuti, Prisoner Rumah Tahanan Negara Klas II B Tanjung Pura Langkat, interview, 14 Januari 2020.

${ }^{43}$ Hidayatul Husna, Prisoner Rumah Tahanan Negara Klas II B Tanjung Pura Langkat, interview, 12 September 2019.
} 
laws, such as methods. mandatory bathing until the intention of fasting the sunnah on Monday and Thursday and the ways to obtain halal and haram food. ${ }^{44}$

Understanding the material about morals in its implementation teaches inmates to be good at listening to tausiyah by ustazah well. Material about morals is also applied in prisoners about the manners of reading the Koran, how to read the Koran, together with other inmates to deepen their reading of the Koran. Prisoner Mrs. Hidayatul Husna said:

Valuable lessons learned from Islamic morals, including teaching to do good to oneself, the environment, and mutual respect among friends. Can be grateful for the blessings that Allah has given. ${ }^{45}$

Providing tausiyah about the History of Islamic Culture to inmates aims to provide religious knowledge about the story of the Apostles, the companions of the Prophet Muhammad. who belong to khulafaur rashidin, the priests of the mazhab, and the repentance of other friends. Tausiyah with this material gives new knowledge to inmates that the life of a Prophet also goes through very difficult times in the path of truth, especially friends and other pious people all go through difficult times in living the truth.

The success of the implementation of non-formal Islamic education at Rumah Tahanan Negara Klas II B Tanjung Pura Langkat certainly has supporting factors, namely:

There is cooperation from various parties. The cooperation in question is a collaboration that is continuously established in the State Detention Center with the Ministry of Religion of Langkat Regency which assigns its employees to take part in the process of fostering both prisoners and detainees, to officers who always provide supervision during the implementation of Islamic education.

Attitude of prisoners. During their detention period, the prisoners showed a good attitude, this was also reflected when the extension team or ustadzah came to Rumah Tahanan Negara to give tausiyah. From the results of the researcher's analysis, the enthusiasm of the prisoners was very visible when he saw the ustazah entering the study room on the second floor of Rumah Tahanan Negara which is on the north left side of Block F, from under their room at Rumah Tahanan Negara while saying: "Umi today we pay, let's get ready for a moment ". Even so, the enthusiastic attitude of the prisoners in learning religion is no less enthusiastic, even most of them feel that time flies so quickly.

Facilities. Carrying out non-formal Islamic education activities at Rumah Tahanan Negara Klas II B Tanjung Pura. One of the supporting factors is the existence of facilities and facilities provided by Rumah Tahanan Negara for this activity, such as a mosque and a place to study on the 2nd floor of Rumah Tahanan Negara. tables and chairs and a fan on the wall in the right corner of the wall of Rumah Tahanan Negara, but several other inadequate facilities and infrastructure, such as the absence of a blackboard, chalk/markers, reading books in the library are also incomplete and inadequate, books are not yet available writing

44 Salmilawati Hasanah, The Head of The Tanjung Pura Islamic Religion Counselor Team, interview, 9 Oktober 2019.

${ }^{45}$ Husna, Prisoner Rumah Tahanan Negara Klas II B Tanjung Pura Langkat. 
and other writing instruments for prisoners when studying Islam at the Langkat Rumah Tahanan Negara.

The majority of residents of Rumah Tahanan Negara are Muslim. Another thing that supports the implementation of this non-formal Islamic education, most of the prisoners, both male, and female, are Muslim. This is what motivates us to collaborate with Kementerian Agama Islam Kabupaten Langkat to carry out religious guidance with the aim that prisoners can change their behavior and not repeat acts that violate criminal law.

\section{CONCLUSION}

Islamic religious education is not only implemented in school institutions in Rumah Tahanan Negara, education for prisoners has also been implemented, aimed at restoring the prisoner's understanding of the crimes they have committed. Islamic religious education taught to prisoners is guided by the Koran and Hadith.

The implementation of Islamic Religious Education has the aim of improving the quality of the assisted citizens so that they become fully human, pious, healthy, and responsible to themselves, their families, and society, so that they can integrate themselves into society, can again play a role as members of society who are free and responsible. ${ }^{46}$

Based on Law Number 12 of 1995 concerning Corrections, article 14 points (a), (b), and (c), namely: Prisoners have the right: To Performing worship by religion or belief. Obtain good physical and spiritual care. Obtain education and teaching. With the existence of Islamic education, it's hoped that the prisoners will be able to convert and return to the right path and be strong in living their post-prison life.

In collaboration with Islamic religious extension workers from Kementerian Agama Islam Kabupaten Langkat, it also implements management functions, namely planning, organizing, implementing, and monitoring. The activity is scheduled once every two weeks in a month with material on the eradication of literacy in the Koran, group dynamics and leadership, introduction to Islam, morals, fiqh, and Islamic culture. The success obtained was a change in the behavior and attitude of the prisoners for the better. This is inseparable from the support and cooperation of various parties, the facilities that support the majority of female prisoners are Muslim.

\section{REFERENCES}

Abdulsyani. Sosiologi: Skematika, Teori Dan Terapan. Jakarta: Bumi Aksara, 1994.

Apriyanti. Prisoner at Rumah Tahanan Negara Klas II B Tanjung Pura Langkat. Interview, 21

November 2019.

Arikunto, Suharsimi. Manajemen Penelitian. Jakarta: Rineka Cipta, 2009.

Astuti, Sri. Prisoner Rumah Tahanan Negara Klas II B Tanjung Pura Langkat. Interview, 14 Januari 2020.

Direktorat Jenderal Pemasyarakatan Kementerian Kehakiman dan Hak Asasi Manusia RI. Petunjuk Pelaksanaan Program Pendidikan Agama Islam Dengan Kurikulum Modul A bagi Narapidana Di Lembaga Pemasyarakatan dan Rumah Tabanan Negara. Jakarta, 2001.

Emqi, Muhammad Fauzy. "Model Pembelajaran Pendidikan Agama Islam Dalam Pembinaan Mental Narapidana (Studi Multikasus di Lembaga Pemasyarakatan Kelas I Malang 115.

${ }^{46}$ Hasbiyallah dan Asy-Syari, "Pelaksanaan Pendidikan Agama Islam Bagi Narapidana Kasus Korupsi,” p 
Dan Lembaga Pemasyarakatan Wanita Kelas II-A Malang)." J-PAI: Jurnal Pendidikan Agama Islam 1, no. 1 (30 Desember 2014). https://doi.org/10.18860/jpai.v1i1.3359.

Fakih, Mansour. Analisis Gender dan Transformasi Sosial. Yogyakarta: Pustaka Pelajar, 2005.

Fitri, Wanda. "Perempuan dan Perilaku Kriminalitas: Studi Kritis Peran Stigma Sosial Pada

Kasus Residivis Perempuan.” Kafa ab: Journal of Gender Studies 7, no. 1 (22 Juni 2017): 67. https://doi.org/10.15548/jk.v7i1.155.

Hasanah, Salmilawati. The Head of The Tanjung Pura Islamic Religion Counselor Team. Interview, 9 Oktober 2019.

Hasbiyallah, Hasbiyallah, dan Siti Fadhilah Asy-Syari. "Pelaksanaan Pendidikan Agama Islam Bagi Narapidana Kasus Korupsi." Atthulab: Islamic Religion Teaching and Learning Journal 4, no. 1 (18 Februari 2019). https://doi.org/10.15575/ath.v4i1.2862.

Heri, Totong. "Pembinaan Kesadaran Beragama Sebagai Upaya Peningkatan Pemahaman Agama Islam Di Lapas Kelas IIB Anak Wanita Tangerang." Jurnal Pendidikan Islam 10, no. 2 (30 November 2019): 142-55. https:// doi.org/10.22236/jpi.v10i2.3966.

Husna, Hidayatul. Prisoner Rumah Tahanan Negara Klas II B Tanjung Pura Langkat. Interview, 12 September 2019.

Iriadi. Kasubsi Pelayanan Tahanan Rumah Tahanan Negara Klas II B Tanjung Pura Langkat. Interview, 15 Januari 2020. Rumah Tahanan Negara.

Kalsum, Umi. Prisoner Rumah Tahanan Negara Klas II B Tanjung Pura Langkat. Interview, 14 Januari 2020.

Kansil, C. S. T., dan Christine S. T. Kansil. Hukum Tata Negara Republik Indonesia. Ed. rev. Jakarta: Rineka Cipta, 2000.

Kartono, Kartini. Psikologi Wanita 1 : Mengenal Gadis Remaja \& Wanita Dewasa. Bandung: CV. Mandar Maju, 2019.

Malihah, Noor, dan Agus Wijayanto. "Implementasi Kurikulum Pembinaan Pendidikan Agama Islam di Rumah Tahanan Negara Kelas IIB Salatiga." INFERENSI: Jurnal Penelitian Sosial Keagamaan 12, no. 2 (31 Januari 2019): 349-70. https://doi.org/10.18326/infsl3.v12i2.349-370.

Meleong, Lexy J. Metologi Penelitian Kualitatif. Bandung: PT Remaja Rosdakarya, 1989.

Muchlis. "Peran Penyuluh Agama Islam Fungsional dalam Melakukan Pembinaan terhadap Narapidana di Rumah Tahanan Kelas II-B Kabupaten Bangkalan(Perspektif Komunikasi Sosial dan Agama)." Dirasah : Jurnal Studi Ilmu dan Manajemen Pendidikan Islam 3, no. 2 (8 Agustus 2020): 12-32. https://doi.org/10.29062/dirasah.v3i2.123.

Muthahhari, Murtadha. Hak-Hak W anita Dalam Islam. Jakarta: Lentera, 1997.

Nursiah, Syair. Tanjung Pura Islamic Religion Conselor Team. Interview, 16 Januari 2020.

Pelani, Herman, Bahaking Rama, dan Wahyuddin Naro. "Kegiatan Keagamaan Sebagai Pilar Perbaikan Perilaku Narapidana Di Lembaga Pemasyarakatan Wanita Kelas IIA Sungguminasa Gowa." Jurnal Diskursus Islam 6, no. 3 (24 Desember 2018): 444-58. https://doi.org/10.24252/jdi.v6i3.6545.

Prastowo, Andi. Metode Penelitian Kualitatif: Dalam Perspektif Rancangan Penilitian. Yogyakarta: Ar-Ruzz Media, 2013.

Rina Saraswaty, Suprayitno, dan Salamiah Sari Dewi. "Pemberdayaan Napi Perempuan Di LP Tanjung Gusta Kecamatan Medan Helvetia, Medan, Sumatera Utara.” Randang Tana - 
Jurnal Pengabdian Masyarakat 3, no. 3 (2020): 140-48. https://doi.org/10.36928/jrt.v3i3.644.

Romi. Head Rumah Tahanan Negara Klas II B Tanjung Pura Langkat. Interview, 14 November 2019.

Santosa, Slamet. Dinamika Kelompok. Jakarta: Bumi Aksara, 1992.

Siregar, Parlindungan. Head of Rumah Tahanan Negara Klas II B Tanjung Pura Langkat. Interview, 13 Januari 2020.

Subhan, Zaitunah. Kodrat Perempuan: Takdir Atau Mitos? Yogyakarta: Pustaka Pesantren, 2004.

Sujatno, Adi. Sistem Pemasyarakatan Indonesia: Membangun Manusia Mandiri. Jakarta: Depkeh \& HAM, 2004.

Ula, Siti Thohurotul. "Makna Hidup Bagi Narapidana." Hisbab: Jurnal Bimbingan Konseling dan Dakwah Islam 11, no. 1 (1 Juni 2014): 15-36. https://doi.org/10.14421/hisbah.2014.111-02.

Yulia Khoerunnisa dan Muhammad Rosyid Ridla. "Strategi Peningkatan Spiritualitas Narapidana Di Lembaga Pemasyarakatan: Studi Pada Lapas Perempuan Kelas II B Yogyakarta." Jurnal MD 6, no. 1 (2020). https:// doi.org/10.14421/jmd.2020.61-04. 